\title{
Anti-Inflammatory Effects of Magnetically Targeted Mesenchymal Stem Cells on Laser-Induced Skin Injuries in Rats [Corrigendum]
}

Li X, Wei $\mathrm{Z}$, Zhang $\mathrm{W}$, et al. Int $J$ Nanomedicine. 2020;15:5645-5659.

The authors have advised due to an error at the time of figure assembly, Figure 8 on page 5657 is incorrect. The correct Figure 8 is shown below.
The authors apologize for this error and advise it does not affect the results of the paper.

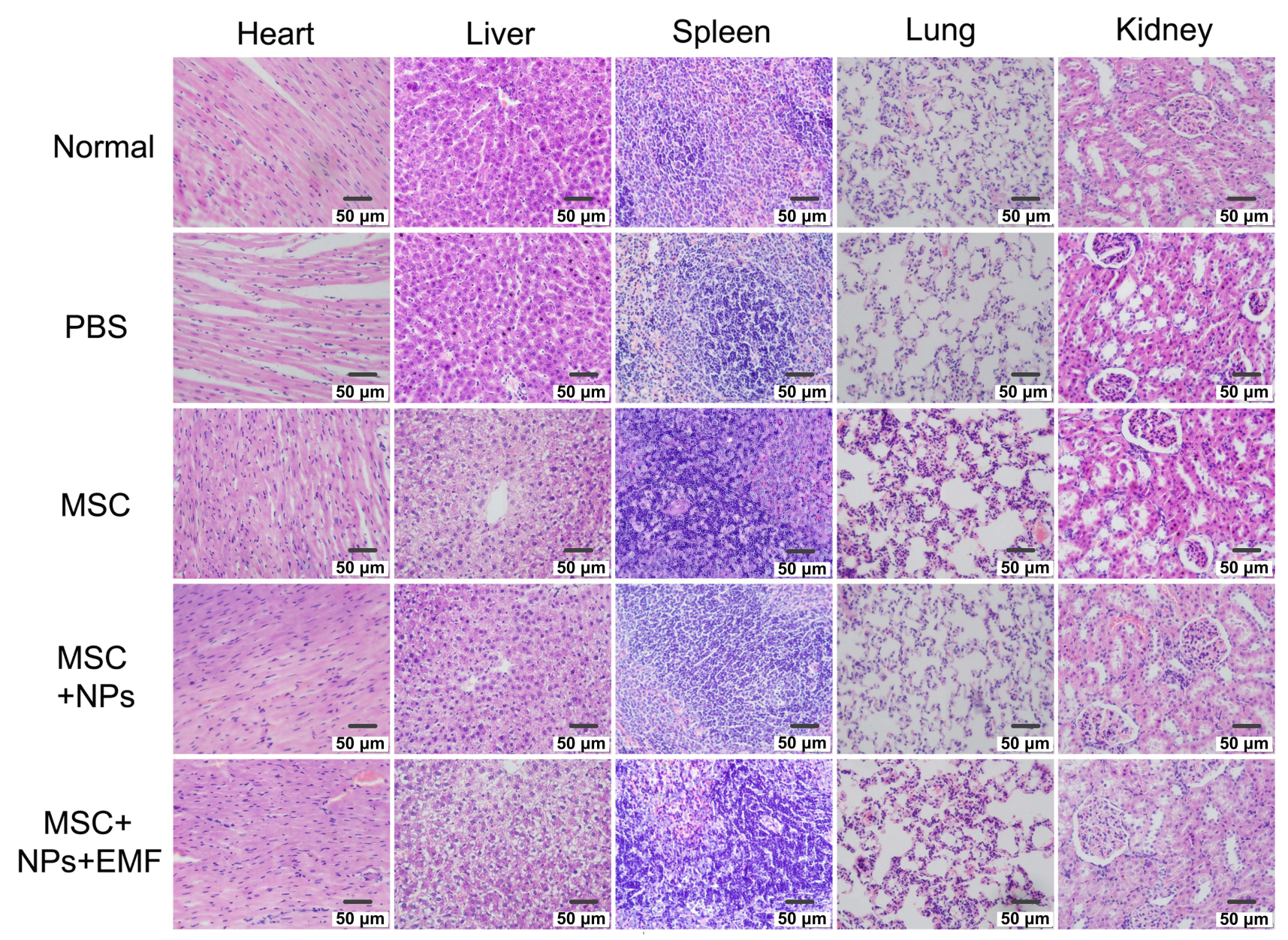

Figure 8 H\&E staining of the heart, liver, spleen, lung, and kidney at 7 days after tail-vein injection of PBS, MSCs, NP-labeled MSCs, or magnetically targeted MSCs. Scale bar = $50 \mu$ m. 


\section{Publish your work in this journal}

The International Journal of Nanomedicine is an international, peerreviewed journal focusing on the application of nanotechnology in diagnostics, therapeutics, and drug delivery systems throughout the biomedical field. This journal is indexed on PubMed Central, MedLine, CAS, SciSearch ${ }^{\mathbb{B}}$, Current Contents ${ }^{\mathbb{B}} /$ Clinical Medicine,
Journal Citation Reports/Science Edition, EMBase, Scopus and the Elsevier Bibliographic databases. The manuscript management system is completely online and includes a very quick and fair peer-review system, which is all easy to use. Visit http://www.dovepress.com/ testimonials.php to read real quotes from published authors.

Submit your manuscript here: https://www.dovepress.com/international-journal-of-nanomedicine-journal 